\title{
Production Analysis of Green Mussel (Perna viridis) in Lampung Province
}

\author{
Sulvina*1, Zainal Abidin, Supono*2 $^{* 2}$
}

\begin{abstract}
This study was conducted to find out factors affecting and level of mussel production, level of efficiency of using the tools and materials in cultivation process and whether the cultivation of mussels in Pasaran. This study was analyzed using Cobb-Douglass. The study were analyzed in quantitative descriptive, multiple linear regression analysis, and analysis of efficiency. The dependent variable $(Y)$ is the result of production of green mussels cultivation and free variables are the number of bamboos (X 1), the amount of strap (X2), grouper (X3) and labor (X4). Mussel fisherman in Pasaran NPM with Px calculated to obtain the level of efficiency of each factors of production in messels cultivation. Studies show that the most influential factors production are variable bamboo, rope and labor. While the results of analysis the level of efficiency of using tools and materials is not efficient. The number of bamboo and labor should be reduced, because it tends to be a waste and not profitable either technically or economically. The value of the return to scale of 1.22 showed cultivation mussels are on increasing return to scale.
\end{abstract}

\section{Keywords: Production factor, efficiency, green mussels, Pulau Pasaran}

\section{Introduction}

The shells are one of the many fisheries resources obtained through interception in nature, such as mussels, clams, oysters, and tridacna. Green Mussel (Perna viridis) is a biological resource that has a high economic value (Ferdinand et al., 2017). One of the areas in Lampung Province developed for the cultivation of mussels is Pasaran Island. Pasaran Island is located in the Sub-District of Teluk Betung East, Bandar Lampung.

\footnotetext{
${ }^{1}$ E-mail: sulvina01@yahoo.com

${ }^{2}$ Coastal and Marine Management Program, Lampung University

Jl. Prof. S. Brodjonegoro No.1 Gedong Meneng Bandar Lampung, 35145
}

Species of the family Mytilidae green mussels a specific continent of Asia is rife from the Persian Gulf to India, the Philippines, Taiwan, Vietnam, and Northeast China (Cappenberg, 2008). The larvae green mussels formed after 12 to 15 hours after the eggs are fertilized and on day 8 leg muscles (byssus) began to be used for edging and swimming freely. During the period of time about 8 days. The larvae reach the completion stage on day 9, which has a shorter time. Overall, the larvae cannot be controlled by the temperature of the sea water, but also by the food that is 
in the waters (Ompi and Svane, 2018). Larvae green mussels spread through the current or ballast until finally attached to a substrate (Pitaloka, 2015).

Cultivation of green mussels in the Pasaran Island strongly influenced by nature. The high demand for green mussels every year in the market makes profits for farmer scallops in Pasaran Island. But the needs of mussels are still not can be fulfilled (Ferdinan et al., 2017). Cultivated mussels will be safer for consumption than the result of nature (Andalecio et al., 2014).

\section{Methods}

\section{Diet Preparation}

The study used the census method so that the respondents were the entire green mussel farmers on the Pasaran island of 99 people. The data used are primary and secondary data. Primary data can be obtained by direct interviews based on the questionnaire guidelines. The main question in the questionnaire were about the characteristics of the respondent's family, the amount of green mussel production on the Pasaran island and the cost used for cultivation to harvest. It also obtained direct observation that all reflect the condition of the study area. Secondary data can be obtained from some important literature such as statistics, report of research results, journal and so forth that can support the completeness of the study data.

\section{Data Analysis}

This research was conducted on the Pasaran Island, Bandar Lampung, Lampung. The variable used is the number of bamboo (X1). Bamboo is a material used for the cultivation of green shellfish. Based on Sulvina's research (2015), bamboo is tool used to tie a rope or a substrate. The number of ropes (X2), the rope is as a substrate where the attachment of green mussel seeds until ready to harvest. Duration of karamba usage (X3), this variable of durability of karamba usage will be seen whether it affects the production of green mussel well or reduce production quantity. While labor is the amount of labor used whether it affects during the process of mussel cultivation or not. The amount of production $(\mathrm{Y})$ is the amount of production of green mussel cultivation in one harvest cycle while the production factor price is often written with $(\mathrm{Px})$. (Gujarati and Porter, 2015).

The relevance of production factors was analyzed using the CobbDouglas. Before analyzed using Cobb-Douglas production function, the data is tested using classical assumption test. The classical assumption test is performed to test the calculation results so as not to produce a biased equation (Gujarati, 1999). The classical assumption test includes the normality test. It aims to find out whether what normal distribution data does not by looking at the value of the ratio of kurtosis and skewness is between -2 to +2 , so the data distribution is normal (Santoso, 2000). Auto correlation test is a statistical analysis conducted to determine whether there is a correlation of variables that exist in the prediction model with time changes.

The purpose of the autocorrelation test is to know 
whether there are correlations of variables that exist in the prediction model with the time change. Multicollinearity test aims to test whether in the regression model found the correlation between independent variables or not. A good regression model should not be correlated among the independent variables (Ghozali, 2012). The heterocedastic test aims to determine whether in the regression model there is a variance inequality of the residual one observation to another observation (Setiawati, 2006). In addition to using the classical assumption test is also a goodness of fit test is the determinant coefficient analysis (R2) aims to determine the level of accuracy is best in regression analysis. This is indicated by the magnitude of the coefficient of determination $\left(\mathrm{R}^{2}\right)$ between 0 and 1 . If the coefficient of determination approaching one then it can be said that the independent variables affect the dependent variable (Gujarati, 2006). F test is performed to determine whether the production factors used simultaneously has real or no effect on the production yield on green shellfish cultivation. $T$ test is a statistical test using t test with a real level (a) 0,05 or a $95 \%$ confidence level needs to be done to test the significance of the returns of scale on dairy farms (Gujarati dan Porter, 2010).

According to Nicholson (1995), price efficiency is achieved when the ratio between the marginal productivity value of each input (NPMxi) and the input price (vi) is equal to 1 . This condition requires NPM, equal to the price of production factor $X$, where the efficiency level of production factors use are calculated using the ratio of the value of the marginal product to $i$ with the price of the input factor I (PXi). The production elasticity of each factor production in the Cobb-Douglas function is expressed in three alternatives showing the scale of business that is increasing return to scale, if $(\mathrm{b} 1+\mathrm{b} 2+\ldots+\mathrm{bn})>1$, it means that the proportion of additional factor will produce an additional proportion, constant return to scale, if $(\mathrm{b} 1+\mathrm{b} 2+\ldots+\mathrm{bn})=1$, it means that the proportion of the addition of a factor of production equals the addition of produced production, and decreasing return to scale, if $(\mathrm{b} 1+\mathrm{b} 2+\ldots+\mathrm{bn})<$ 1(Gujarati and Porter, 2015), it means that the proportion of additional factor will exceed production. Andi (2018) dan Setiawati (2006).

\section{Results and Disscusion}

\section{Characteristics of respondents}

The most respondent of the green mussel farmers on the Pasaran Island was already married, and have dependents in his home (Ali, 2015). This can be seen in Table 1 . The definition of a dependent child and the number of families in this research is the number of the persons who are in one family that his life was borne by the head of the family (Andi, 2018). Family profile of respondents and the number of dependents in the family are presented in table 1 . The number of children and dependents of the soul of the farmers Pasaran Island contains a small number of dependents $1-3$ people, this is caused by the son, owned by respondent/green mussel farmer have 
married and no longer a dependent of Head of the household respondents (Ferdinan et al., 2017).

Table 1. Characteristics of respondents

\begin{tabular}{llrlrlr}
\hline No & Status & $\begin{array}{c}\text { Percent } \\
\%\end{array}$ & $\begin{array}{c}\text { Level of } \\
\text { education }\end{array}$ & $\begin{array}{c}\text { Percent } \\
\%\end{array}$ & $\begin{array}{c}\text { Cultivation } \\
\text { Experience } \\
\text { (Year) }\end{array}$ & $\begin{array}{c}\text { Percent } \\
\%\end{array}$ \\
\hline 1. & Married & 83,8 & $\begin{array}{l}\text { Primary } \\
\text { School }\end{array}$ & 45,5 & $01-$ Feb & 2,0 \\
2. Single & 15,2 & $\begin{array}{l}\text { Junior High } \\
\text { School }\end{array}$ & 34,3 & $3-4$ & 36,4 \\
3. Widower & 1,0 & $\begin{array}{l}\text { Senior High } \\
\text { School }\end{array}$ & 18,2 & $05-$ Jun & 59,6 \\
4. & Separate & 0,0 & College & 2,0 & $07-$ Agust & 2,0 \\
5. & Total & 100,0 & Total & 100,0 & Total & 100,0 \\
\hline
\end{tabular}

The level of education is a factor that is not too important in the cultivation of mussels, for the cultivation of mussels are in the category of the informal sector. The higher education of a person then will choose the formal sector (Ferdinan et al. (2017); Ali (2015)). Educational level of respondent aquaculture mussels spread his education is presented in table 1.

Low levels of education which is owned by the head of the family of farmers green mussels that is on the Pasaran Island in line with the theory of Fahmi (2003) stated that "coastal communities is the community who live in colonies that live in the coastal area with its economy depends on the existing resources generally have a low education level (Noor, 2015).

Experience level of farmers trying to produce mussels in addition seen from the success of the activities of cultivation mussels depends on the availability of the seed of nature (Ferdinan, 2017), environmental conditions ideal waters so that can support the growth of the biota and aquaculture (Sundari and Yudhi, 2016), and lack of predators or diseases (Vakily, 1989). The experience level of the respondents against the green mussel cultivation in the Pasaran Island is presented in Table 1.

Based on the information in the field, cultivation of mussels in the Pasaran Island started at the early 2011. Within a period of 7 years is the better development of the cultivation of green mussels. Based on the experience of the indicator that is owned by farmers ' mussels in choosing the time and the right tools and materials to be used at the time of cultivation is also sorely needed (Noor (2015); Ferdinan (2017)). Green mussel farmers on Pasaran Island has experience that is already pretty long in cultivation of mussels. A long cultivation of mussels does not affect the result of the production of green mussel aquaculture it self (Sulvina et al., 2015). Aquatic animals will show significant effects 
due to low $\mathrm{pH}$ or other water quality, it means the production of aquatic animals will be on the influence by various factors (Nyanti, 2018).

\section{Construction mode}

The result of the test assumptions of classical that data is worth to use. There are 4 classic assumption test used in this study, A classic assumption test done to test the results of the calculations in order not to produce the equation bias.
These include classic assumption test for multicollinearity, normality tests, heteroskedastisitas test (Gujarati, 2006), autocorrelation test and test of linearity (Setiawati, 2006). The data was processed using spss 16 .

Before done analysis of the Cobb-douglas first conducted regression analysis. Following the results of the regression analysis of the influence factor on the fourth in the Table 2.

Table 2. The estimation results are presented in the estimation of the factors that influence the cultivation of Mussels in the island market.

\begin{tabular}{|c|c|c|c|}
\hline Variabel & $\begin{array}{l}\text { Koefisien Beta } \\
\text { Standardized } \\
\end{array}$ & t-ratio & Sig \\
\hline Konstanta & 0,1148 & 6,494 & \\
\hline $\mathrm{X}_{1}($ Bamboo $)$ & 0,130 & 4,660 & 0,000 \\
\hline $\mathrm{X}_{2}$ (Rope) & 0,898 & 21,401 & 0,000 \\
\hline $\mathrm{X}_{3}$ (Vulnerability Karamba) & 0,189 & 4,362 & 0,000 \\
\hline $\mathrm{X}_{4}$ (Labor) & 0,003 & 0,174 & 0,863 \\
\hline $\mathrm{R}^{2}$ & 0,964 & & \\
\hline $\mathrm{F}$ & 630,121 & & \\
\hline $\mathrm{N}$ & 99 & & \\
\hline $\mathrm{D}-\mathrm{W}$ & 1,882 & & \\
\hline
\end{tabular}

Judging from the results of the estimation, of the four independent variables included in the regression, variable labor is not significant. While bamboo, ropes and Vulnerability Karamba significant at 0.05. Cobb-Douglas Function. From
Table 2 can be inferred that the variables of production influenced by bamboo, ropes and long wearing of grouper, with mathematical equations:

$$
\text { Production }=0,1148+0,130+0,898+0,189+0,003+e
$$

- Constants of 0,1148 pointed out that if the independent variable is considered constant, then the production of green mussel clam $0,1148 \mathrm{~kg}$.

- The regression Coefficient of bamboo-0,130 states that any additions bamboo amount will increase production of mussels.

- The regression coefficients of strap 0,898 States that any additions will increase the amount of rope mussels.

- The regression CoefficientsVulnerability Karamba usage of 
0,189 stated that any addition of a usage long grouper will increase production of mussels.

- The results of the estimation of the factors of production the cultivation of mussels in the Pasaran Island above that obtained from four (4) independent variables that affect the production of cultivated mussels are significant, namely the variables $\mathrm{X}^{1}$ (bamboo), variable $\mathrm{X}^{2}$ (Rope), $\mathrm{X}^{4}$ (variable Power Work).

While in the variable $\mathrm{X}^{3}$ (old karamba was gradually tapered off) not significant (Jono, 2016). The old variable karamba was gradually tapered off not significant this can be seen from the probability amounting 0,003 (Setiawati, 2006) and Ghozali (2012). Cobb-Douglas function equations need to be tested with the purpose of knowing whether the statistical model used guess worth for production parameters and functions Gasperz (1995) and (Gujarati, 2006).

\section{Efficiency of price}

To answer the two objectives done analysis of the statistical tests. The results obtained from test $t$ of 1,985 and with degrees of freedom 3,397. While the retrieved results from test $F$ of 2,47, while for the degrees of freedom of the R2 2,00 in Table 3 (Setiawati, 2006) dan Andi (2018). Coefficient of determination $\mathrm{R} 2$ or test is to know the extent to which free variables relationship against the variable. If the value of $\mathrm{R} 2$ $=1$, then the influence of the variable bound against free reaches $100 \%$, good influence which are raised as well as the influence that is lowering the variables are bound. But if the value of $\mathrm{R} 2=0$, then the variables are free with absolutely no effect on the variable is bound (Gujarati and Porter, 2010).

Table 3. To answer the purpose of three in obtain the results of the level of efficiency of prices on green sea shell aquaculture activities in the Island Market is presented

\begin{tabular}{lcccccc}
\hline $\begin{array}{c}\text { Free } \\
\text { Variables }\end{array}$ & Koef.B & $\begin{array}{c}\text { The } \\
\text { average } \\
\text { Input }\end{array}$ & $\begin{array}{c}\text { The } \\
\text { input } \\
\text { Union } \\
\text { prices } \\
(\mathbf{R p})\end{array}$ & $\begin{array}{c}\text { Average } \\
\text { production } \\
\text { (KW) }\end{array}$ & $\begin{array}{c}\text { The price of } \\
\text { Production } \\
\text { (Rp.) }\end{array}$ & $\begin{array}{c}\text { The Level } \\
\text { Of } \\
\text { Efficiency } \\
\text { Of The } \\
\text { Usage Of } \\
\text { Infut }\end{array}$ \\
\hline Bamboo & 0,130 & 7,727 & 4,040 & 5,975 & 7,000 & 0,174 \\
Rope & 0,898 & 7,876 & 7,257 & 5,975 & 7,000 & 0,658 \\
Vulnerability & 0,003 & 2,947 & 1,95918 & 5,975 & 7,000 & 0,217 \\
Karamba & 0,189 & 6,435 & 157,575 & 5,975 & 7,000 & 0,007 \\
Labor & & & & & & \\
\hline
\end{tabular}

The efficiency of the bamboo, rope, Vulnerability Karamba and labor on production cultivation of mussels can be seen in table 3. From these data the results of the efficiency of the price of the four input on the cultivation of mussels in the Pasaran Island can be said to be inefficient. These results are consistent with research conducted by Samad and Patwary (2003) in Bangladesh for the textile industry, as well as Cheng 
(2004) for the business in China which concluded that small and medium scale industries have not entirely doing activities in efficient (Chinese Indonesian surname and Imaningati, 2014) (Susanto, 2014).

According to Sulvina (2015) from the four most influential variables against the cultivation of green mussels are the variable string. Production of mussels in the waters of the Pasaran Island is expected to continue to be improved, both of production and mastery of technology of cultivation of good (good aquaculture practices) (Sundari and Yudi, 2016), so the green mussel cultivation can be an alternative effort when not in season anchovies (Noor,
2015). Green mussel cultivation on the island is very prospective Market to be developed so that it can increase the level of social welfare on the Pasaran Island. In addition to the influence of the parameters of the physics, chemistry and biology are very important to get a good meat quality (Gavrilovic et al., 2011).

\section{Return To scale Analysis}

The Results from Return To scale can be seen Table 2 which shows that the number of standardized beta coefficient of the four researchs free variable is less than 1 , namely

$$
\beta_{1}+\beta_{2}+\beta_{3}+\beta_{4}=1,30 X_{1}+0,898 X_{2}+0,189 X_{3}+0,003 X_{4}=1,22
$$

So it can be concluded that the cultivation of mussels in Pasaran island match increasing return to scale (Setiawati, 2006) dan Ghozali (2012). Used amount of elasticity magnitudes $b^{1}, b^{2}, b^{3}, b^{n}$, which has the possibility of greater than one, the same one or smaller than one (Setiawati, 2006). This means that the proportion of the addition of the factors of production (inputs) will produce additional production (output) with a larger proportion of the addition of inputs (Sundari and Yudhi, 2016). The results return to scale showing that mussels farmers will be efficient in the use of factors of production as a whole with the addition of a factor of production (Berliantara et al., 2016). A State of constant return to scale it indicates that if all inputs is increased twice, then the output will be increased twice (Wijianto, 2016).

\section{Conclusion and Suggestion}

\section{Conclusion}

- Production factors that significantly affect the production of green mussel cultivation in Pasaran Island are bamboo variable, string variable, and harvest cycle variable to.

- Cultivation of green mussels on Pasaran Island is not efficient in the use of production factors.

- Cultivation of green mussels on Pasaran Island is included in the principle of increasing return to scale.

\section{Suggestion}

From the existing conclusion can be proposed green mussel training is more optimal, that is, it needs to be done on the use of energy because of loading and not good for the factors of 
production and the amount needed to add to make it more profitable.

\section{References}

Ali, M., Maharani, H.W., Hudaidah, S., and Fornando, H. 2015. Analisis Kesesuain Lahan di Perairan Pulau Pasaran Provinsi Lampung untuk Budidaya Kerang Hijau. Maspari Journal, 8(58): 57 -64 .

Andi, S., Rahmat, K., and Sulistiono. 2018. Penilaian Kondisi Ekologi Perairan Untuk Pengembangan Budidaya Kerang Hijau (Perna viridis L.). Institut Pertanian Bogor. ejournal-balitbang, 57(1): $57-67$.

Andalecio, M.N., Duncan, P.F., Peralta, E.M., Napata, R.P., and Laureta, L.V. 2014 Consumer behavior towards cultured oyster and mussel in Western Visayas, Philippines. AACL Bioflux 7(2): $116-136$.

Berliantara, Wan, A.Z., and Dyah, A.H.L. 2016. Analisis Efisiensi Produksi Dan Keuntungan Usaha Tani Tomat dataran Rendah Di Kabupaten Lampung Selatan. JIIA, 342(1): 342 - 350 .

Cappenberg, H.A.W. 2008. Some aspects of the Biology of the Green Mussel (Perna viridis, Linnaeus 1758). Oseana, 33(1): 33 - 40.

Cheng, Y.S. and Dic Lo. 2004. Firm Size, Technical Efficiency and Productivity Growth in the Chinese Industry. Department of Economics Working Papers. No. 144. The School of Oriental and African Studies University of London, UK.
Fahmi, I. 2003. Strategic management theory and application. Alfabeta, Bandung

Ferdinan, D., Buchori, A. and Irma, B. 2017. Socio-economic conditions of the Fishers Island Mussels Market Sub Teluk Betung East of the city of Bandar Lampung. E-journal of Education University of Lampung 14 things.

Gasperz, V. 1995. Total Productivity Management, Global Business Productivity Increase Strategy. Gramedia Pustaka Utama, Jakarta.

Gavrilovic A., Jug-Dujakovic J., Marinovic Bonacic A., Conides A., Bonacic K., Ljubicic A., Van Gorder S., 2011 The influence of environmental parameters on the growth and meat quality of the Mediterranean mussel Mytilus galloprovincialis (Mollusca:

Bivalvia). AACL Bioflux, 4(5): 573 $-583$.

Ghozali, I. 2012. The application of Multivariate Analysis with SPSS Program. Diponegoro University, Semarang.

Gujarati and Damodar. 1999. The Basic Econometrics, interpreting the Ak. Sumarno Zain, Drs., MBA. Erlangga, Jakarta.

Gujarati, D.N. 2006. The Basics of Econometrics Vol. I. Eason, Jakarta.

Gujarati, D.N., and Porter, D.C. 2010. The basics of Econometrics vol. 1. Translator Eugenia Mardanugraha, dkk 5. Mc Edition Graw-Hill Education.

Gujarati D.N. dan Porter DC. 2015. Dasar-dasar Ekonometrika. Salemba Empat, Jakarta.

Jono. 2016. Analysis of Productivity Of Factory Production Function 
Using A Cobb-Douglas. Spectrum Industries: 109-230.

Nicholson, W. 1995. MicroEconomic theory, the basic principle and the expansion, interpreting Daniel Wirajaya, 520 thing.

Noor, N.M. 2015. Prospects of Development of The Cultivation Of Mussels. (Perna viridis) in Bandar Lampung Pasaran. Aquasains. Journal of the science of fisheries and Aquatic Resources: 239 - 246.

Nyanti, L., Soo, C.L., DanialNakhaie, M.S., Ling, T.Y., Sim, S.F., Grinang, J., Ganyai, T., \& Lee, K.S.P. 2018 Effects of water temperature and $\mathrm{pH}$ on total suspended solids tolerance of Malaysian native and exotic fish species. AACL Bioflux, 11(3): 565 $-575$.

Ompi, M. and Svane, I., 2018 Comparing spawning, larval development, and recruitments of four mussel species (Bivalvia: Mytilidae) from South Australia. AACL Bioflux, 11(3): 576 - 588.

Pitaloka, D.A.N. 2015. Filogeografi Green Mussel (Perna viridis) in Indonesia and the relation to the cross-Line cruise. Thesis. Institut Pertanian Bogor, Bogor.

Samad, Q.A. and Patwary, F.K. 2003. Technical efficiency in textile industry of Bangladesh. an application of frontier production function. International Journal of Information and Management Sciences: 19 - 30.

Setiawati, W. 2006. Analysis of Influence factors of production Towards industrial production Fogging fish in Semarang. Thesis.
Master of Economics and Development Studies.

Soekartawi. 2003. Theory of Economic Production Function analysis of Subjects with CobbDuoglas. CV Of an Eagle, Jakarta. Sulvina, Maharani, H.W., \& Hudaidah, S. 2015. The influence of the different types of the laces Toward the level of Snapping the seed Mussels (Perna viridis). eJRTBP: 471 - 478.

Sundari, R.S. and Yudhi, A.A. 2016. The efficiency of use of Production factors on technology Pendederan Catfish (Clarias sp) Sangkuriang. Journal of Fisheries and Marine Technology, (7): 200 207.

Susanto, H.A., and Imaningati, s. 2014. The level of production efficiency and revenue on Processing anchovies small scale. Journal of Economics and Policy: $73-84$.

Vakily, J.M. 1989. The biology and culture of mussels of the genus Perna. ICLARM Stud. Rev. 17, Manila.

Wijianto and Ika, F.U. 2016. The influence of Social Status and Family economic conditions against the motivation to work for Early Adolescents (age 12-16 Years) in Ponorogo. 21 Tijarah Al things. 
